\title{
Implication of mineralogical attributes to define the provenance geology of sediments deposited in Prydz Bay, East Antarctica \\ Rashmi Gupta ${ }^{1 *}$, Mayuri Pandey ${ }^{1}$, N. V. Chalapathi $\mathrm{Rao}^{1}$, N. C. Pant ${ }^{2}$ and Devsamridhi Arora ${ }^{2}$ \\ 1. Department of Geology, Banaras Hindu University \\ 2. Department of Geology, University of Delhi
}

*Correspondence:rashmigupta621@gmail.com

East Antarctica, covered with a very thick sheet of ice and preserves some key geological events of formation, evolution and break-up of supercontinent such as Gondwanaland (e.g. Dalziel, 1991; Moores, 1991). Present study focuses on the detailed geochemical analysis of heavy mineral population of sediments recovered from the Prydz bay, to find out the provenance of these sediments (recovered from ODP Leg 119). Varying composition of garnets, amphiboles and pyroxenes along with some accessory minerals like monazite, zircon, ilmenite, and aluminosilicate indicate the presence of medium to high grade metamorphic rocks (like gneisses and charnokites) and felsic, alkaline and mafic to ultramafic and igneous rocks in the source area. U-Pb dating of detrital monazite from the offshore sediments give the Grenville age (1068 $\pm 9 \mathrm{Ma})$ and Pan African age (531 \pm 3$)$. Alkaline rocks of similar ages ( $\sim 500 \mathrm{Ma})$ are reported from Beaver Terrane, Prydz Bay, Vestfold Hills and throughout the Ruker Terrane (Mikhalsky et al., 2001). U-Pb age data and composition of heavy mineral assemblage (recovered from Prydz bay) suggest that Rayner Province, Ruker province and Granulite-facies metamorphic rocks $(\sim 1000-820 \mathrm{Ma})$ and (570-520 Ma) of Prydz complex (Kinny et al. 1993) and Fitzsimons (2003) are the possible sources of sediments in Prydz bay. 